etc., and of waders like godwits, stilts, green-, woodand curlew-sandpipers, Kentish plovers and of duck such as pintail, garganeys and a few widgeon. There are common, purple, squacco and night herons, spoonbills, storks, glossy ibises, singly or in great flocks, trips of ruffs by the water, swallows, house-martins, sandmartins and swifts over the water. Most of these birds may be seen passing through Egypt by the Nile or down the Suez Canal, where the Kentish plover nests on the marshes. In north Egypt in winter may be seen such British birds as song thrushes, robins, blackbirds, starlings, skylarks and lapwings in some numbers.

\section{Earthquakes in Rumania and Turkey}

ON October 22 earthquakes shook many districts in Rumania and Turkey. Earthquake tremors of medium intensity were registered in Bessarabia, Kieff, Kharkoff and elsewhere in the Ukraine, apparently coming both from the Carpathians and the Caucasus. On the same morning about 8.30 a.m. (local time) a severe shock was felt at Barlag close to Basau near the Carpathians, where children were injured and one boy killed when the roof of a school collapsed. Many other houses were damaged, and some people were unable to stand at the time in the streets. In Bucharest the shock is said to have been the most severe for many years. It is reported to have been a double shock, of total duration according to human perception of about thirty seconds, and to have caused considerable cracks in several stucco buildings besides breaking windows and shaking movable objects (modified Mercalli scale VII). No one was injured in the capital.

Apparently about the same time as the Rumanian shocks the Turkish port of Smyrna was rocked by a severe earthquake, though no serious damage or casualties have been reported. It appears unlikely that the shakings in Rumania and Turkey were due to the same earthquake as surface waves of moderate intensity are soon damped out. Further information from the seismological observatories is awaited before the exact times and epicentres of the shocks can be worked out. Earthquakes in all these regions are not uncommon. Prior to being affected by the great Anatolian earthquake of December 26, 1939, Smyrna was seriously damaged by earthquakes on March 31, 1928, and on September 20, 1899.

\section{Electrical Engineers and the War}

IN his presidential address to the Institution of Electrical Engineers delivered on October 24, Mr. J. R. Beard, of Messrs. Merz and McLellan, gave first a short account of the war-time activities of electrical engineers, and then made many thoughtful comments on the planning of the post-War world. He said that in this War, engineering, technological and scientific problems are playing a greater part than ever before, and that the many branches of electrical engineering have all been directly or indirectly engaged in war activities. The Institution of Electrical Engineers has now the largest membership of any British professional institution. During the past year, the membership has exceeded 20,000 and its responsibilities are correspondingly great. He mentioned particularly the strenuous work undertaken by those engaged in the light current branches. These include such vital services as communications and broadcasting, and the design and manufacture of the apparatus for them and of the similar apparatus for the rapidly expanding needs of the Royal Navy, the Army and the Royal Air Force. In particular, those engaged upon research and development in the multifarious new applications of wireless deserve special record.

Some 1,285 members of the Institution are on active service with His Majesty's Forces, but, unlike the position in the War of 1914-18, almost all of these are engaged in a technical capacity which makes use of their specialized knowledge. The bitter experience of 1914-18, when so much technical talent was wasted through trained men being drafted from productive work into non-technical units, was fortunately taken to heart in good time. Some time before the War broke out, the Ministry of Labour organized the schedule of reserved occupations. On the whole, this has functioned admirably. The Institution has always taken pride in the number of its overseas members, which now amounts to one fifth of the total membership. For many years there have been local centres in the Argentine and China, and there are sixteen local honorary secretaries and twelve overseas committees in many parts of the world. These are an invaluable liaison between distant members and headquarters. Much attention has been given to increasing these contacts with the engineering institutions in the Dominions and India. At a time when the joint defence of our liberties in face of the assault on all free peoples is forging still closer the links of the British Commonwealth of Nations-and indeed of all English-speaking peoples - Mr. Beard reminded members of the Institution overseas that their share in the war-time activities of our various countries is in no way less important than the work of members at home, and that this is recognized and appreciated. Plans for yet closer collaboration after the War are eagerly anticipated.

\section{Early Harbour Engineering}

IN his presidential address to the Institution of Civil Engineers delivered on November 5, Sir Leopold Saville said that since the branch of engineering with which he had been principally associated was harbour engineering, he proposed to deal with harbours from the dawn of written history to the early days of the Roman Empire. He reviewed first the development of the four harbours of Alexandria, namely that of A-ur, about 3000 B.C. ; the great harbour of Pharos, soon after 2000 B.c.; the harbour of Alexander the Great, begun in 332 B.c. ; and the modern harbour, A.D. 1870. He then turned to the pre-Hellenic harbours of Tyre. By 1400 B.c. the renown of the city was widespread, and by 1100 B.c. its seamen had passed Gibraltar and had dared the Atlantic. It was probably about that time the Sidonian harbour was built; Hiram, king of Tyre (970-936 B.c.), built the 